\title{
THE ANALYSIS OF FOREIGN DIRECT INVESTMENT AND ITS AFFECTING FACTORS IN INDONESIA
}

\author{
Fuji Astuty \\ Universitas Prima Indonesia, \\ Email: fujiastuty@gmail.com
}

\begin{abstract}
Foreign Direct Investment gave benefits in improving Indonesia's economics matters in Indonesia. Conseptually, Foreign Direct Investment (FDI) more benefecial because no return to the investor such as debt in foreign country, beside Foreign Direct Investment (FDI) in a country will be followed by transfer of technology, know-how, management skills, the risks of business was smaller and more profitable. However, the problem of global economic that occured affecting the development of Foreign Direct Investment (FDI) in Indonesia decreased and the growth became slowly. Then domestic and global factors weren't stable influencing the decrease Foreign Direct Investment (FDI) in Indonesia. Therefore, it's needed to examine the factors influencing Foreign Direct Investment (FDI). This study aimed to know and analyze some factors affecting Foreign Direct Investment (FDI) in Indonesia consisting gross domestic product, the level of real interest, exchange rates, labour produtivity, and exports. The affecting analysis be done in short-time by using Error Correction Mechanism = ECM technique. It was used time series data from 2000 to 2013 using Eviews 6.0. The type of data used was secondary data obtained from Indonesia Bank (BI), Central Bureau of Statistics (BPS), Federal Reserve Bank of St. Louis and United Nations Economic Social Commision for Asia and the Pacific (UNESCAP). The results of this study showed that gross domestic product, the level of real interest, exchange rates, and labour productivity had positive affection significantly on Foreign Direct Investment (FDI) in Indonesia. While the exports had negative affection significantly on Foreign Direct Investment (FDI) in Indonesia. From determination coefficient $\left(R^{2}\right)$ showed that the variables explained 97.13 percent on Foreign Direct Investment (FDI) in Indonesia while the rest 2.87 percent was explained by variables out of models (not studied).
\end{abstract}

Key words: Foreign Direct Investment, Gross Domestic Product, the level of Real Interest, Exchange Rates, Labour Produtivity, and Exports

\section{INTRODUCTION}

s a developing country, Indonesia needs a significant amount of funds in
national development. In the context of national and regional development, in Zaenudin, 2009: 156). This requires a number of investments financed by national savings. However, national savings, which are a source of national development funds, have limitations, so the government must increase foreign sources of funds. 
Sources of foreign funds can come from foreign debt or foreign capital flows or foreign investment. Conceptually, foreign investment or foreign investment is considered more profitable because it does not require a repayment obligation to foreign parties such as foreign debt. (Zaenudin, 2009: 56). Foreign investment is one of the important sources of financing for developing regions and is capable of making a large enough contribution to development. Thus triggering competition among countries to attract investors by offering various incentives. In this regard, the government is trying to attract foreign investors to invest in Indonesia. Thus the Government regulates policies regarding foreign direct investment in Law no. 1 of 1967 concerning Foreign Investment. Then the Law was completed and perfected in 1970, namely Law No. 11 of 1970. Over time the government issued Law no. 25 of 2007 as a substitute for the previous law. Through foreign direct investment activities, it provides very influential benefits in improving the economy in Indonesia. So that foreign direct investment has a positive effect on the economic development of a country.

The development conditions of foreign direct investment in Indonesia from 2008 to 2013 are presented in the following figure:

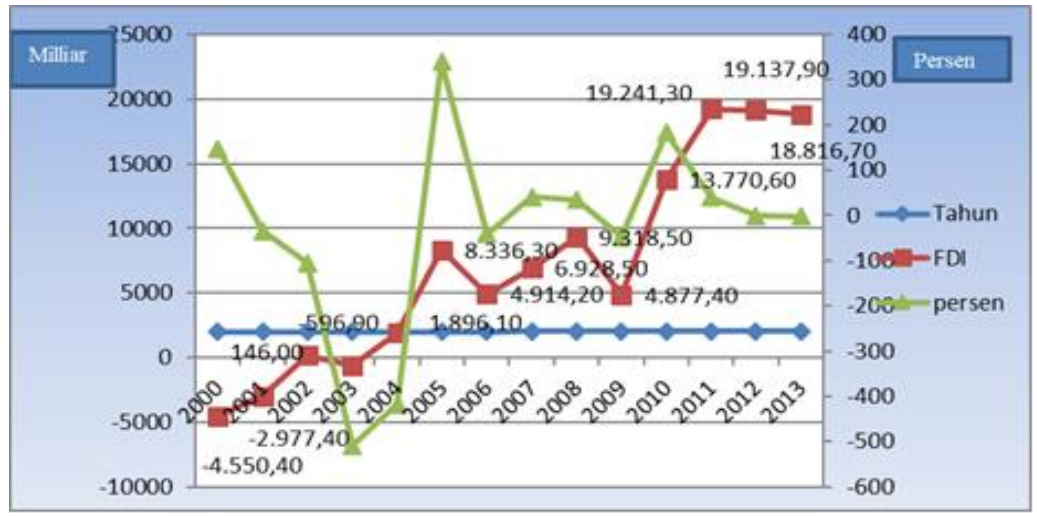

Figure 1: Foreign Direct Investment (FDI) 2008 - 2013

The figure above shows that foreign direct investment in Indonesia in 2008-2013 experienced fluctuating developments. Global economic shocks, as happened recently, significantly affect the Indonesian economy. This is related to the structure of capital flows into Indonesia, which is still dominated by portfolio investment. Meanwhile, foreign direct investment (FDI), which is relatively more sustainable in its development, is still relatively small, due to the fact that Indonesia's competitiveness has not improved. The growth of foreign direct investment into Indonesia has slowed down. Based on the UNCTAD report, the performance of FDI in Indonesia is the lowest compared to other ASEAN member countries. Apart from Cambodia, which also experienced a decline, all countries in Southeast Asia experienced growth in the value of foreign direct investment. (Setyowati, 2014). As a form of capital flow that is relatively vulnerable to economic turmoil, it is hoped that foreign direct investment will help promote sustainable investment growth in Indonesia. However, the development of foreign direct investment in Indonesia shows that foreign direct investment in Indonesia always fluctuates and the increase in foreign direct investment in Indonesia is still 
relatively limited compared to other countries. So that this phenomenon becomes interesting to observe further.

For this reason, it is necessary to pay attention to the development of fundamental factors affecting foreign direct investment in Indonesia such as: GDP, interest rates, exchange rates, labor productivity and exports from 2008 to 2013 as follows:

Table 1: Development of Several Economic Indicators in Indonesia, 2008 - 2013

\begin{tabular}{|c|c|c|c|c|c|}
\hline Year & GDP & SB & KURS & Produktivity & EXT \\
\hline 2008 & $2,082,456.10$ & 2.79 & 89.09 & 3.6 & $137,020.40$ \\
\hline 2009 & $2,178,851.00$ & 9.78 & 88.54 & 2.5 & $116,510.00$ \\
\hline 2010 & $2,314,458.85$ & 3.81 & 100.00 & 3.1 & $157,779.10$ \\
\hline 2011 & $2,464,677.00$ & 6.59 & 99.96 & 5.0 & $203,496.60$ \\
\hline 2012 & $2,618,938.00$ & 5.78 & 96.19 & 5.1 & $190,020.30$ \\
\hline 2013 & $2,770,345.00$ & 2.44 & 92.89 & 3.6 & $182,551.79$ \\
\hline
\end{tabular}

The table above explains the development of several indicators affecting foreign direct investment in Indonesia during 2008 to 2013. In the first semester of 2008, Indonesia's economic growth in general still contributed to the labor market. And the open labor unemployment rate had experienced a decline. So in 2008 the productivity of workers was 3.6 percent. However, the global economic crisis, which reached its peak and continues to affect economic conditions in Indonesia in 2009, has an impact on worker productivity so that it has decreased to 2.5 percent. The Indonesian economy continued to improve in 2010, supported by solid domestic demand and conducive external conditions. This has a positive impact on worker productivity. In 2010, the composition of the workforce with basic education backgrounds was on a downward trend. on the contrary, the composition of workers with higher education levels has increased. Likewise in 2011 to 2012, worker productivity increased to 5.1 percent. The global economy that did not match expectations, amidst the support of the domestic economic structure that was not yet strong and unbalanced, contributed to the decline in Indonesia's economic growth in 2013. As economic activity slowed down, the absorption of the economy to workers in 2013 again decreased to 3.6 percent. Entering Q4 / 2008, the deepening global crisis has put pressure on the labor market in Indonesia. This resulted in several companies making adjustments to their operating performance, business efficiency and closing several factories. In addition, exports began to show weakness due to falling commodity prices. The global economic crisis, which peaked in the last quarter of 2008, continued in early 2009. Overall, the strong effect of the global economic slowdown has resulted in exports of goods and services in 2009 being the worst export performance. This decline in export performance and persistently high risk perceptions on financial markets contributed to a slowdown in investment performance. This is in line with the consolidation process that is still being carried out by the banking industry and the real sector in response to economic uncertainty. In 2010-2011, exports experienced a quite high increase. This is in line with the continuing global economic recovery. And this contributed to the high growth of investment 
performance. The increase in international commodity prices also contributed to the high growth of national exports. In addition, it is supported by the ability to take advantage of increased intra-regional trade, particularly countries with an economic orientation towards the domestic economy. However, in 2012-2013, the development of export value in Indonesia experienced a decline. This is due to the slowing global economy as a result of reduced growth in emerging market countries that has reduced demand for Indonesian exports. Export performance has diminished further because at the same time Indonesia's terms of trade deteriorated in line with the downturn in global commodity prices. (Indonesian Economic Report: 2008-2013). Several researchers previously saw several things related to the review of this study. Sarwedi's research (2002) states that economic variables (GDP and exports) have a positive relationship with FDI. Furthermore, according to research by Sitinjak (2011), the real interest rate has a negative and significant effect on foreign direct investment. And Susanto (2012) in his research that worker productivity has a positive and significant effect on foreign direct investment in Indonesia. Likewise, research by Yol and Teng Teng (2010) states that the real exchange rate has a positive and significant relationship to foreign direct investment.

\section{RESEARCH METHOD}

The analysis model used in this study refers to the basic model of multiple linear regression equations with the Engle-Granger Error Correction Mechanism (EG-ECM) method in estimating the short-term relationship between gross domestic product variables, real interest rates, foreign exchange rates, labor productivity and exports by foreign direct investment in Indonesia. The scope of this study focuses on the analysis of the factors that influence foreign direct investment in Indonesia with a time period of 2000 to 2013. In this study, we will examine the factors that influence foreign direct investment, namely gross domestic product, real interest rates, value. exchange, labor productivity and exports.

\section{RESULT AND DISCUSSION}

\section{Development of Foreign Direct Investment in Indonesia}

In general, the picture of foreign direct investment in Indonesia from 2000 to 2013 can be seen in the following figure:

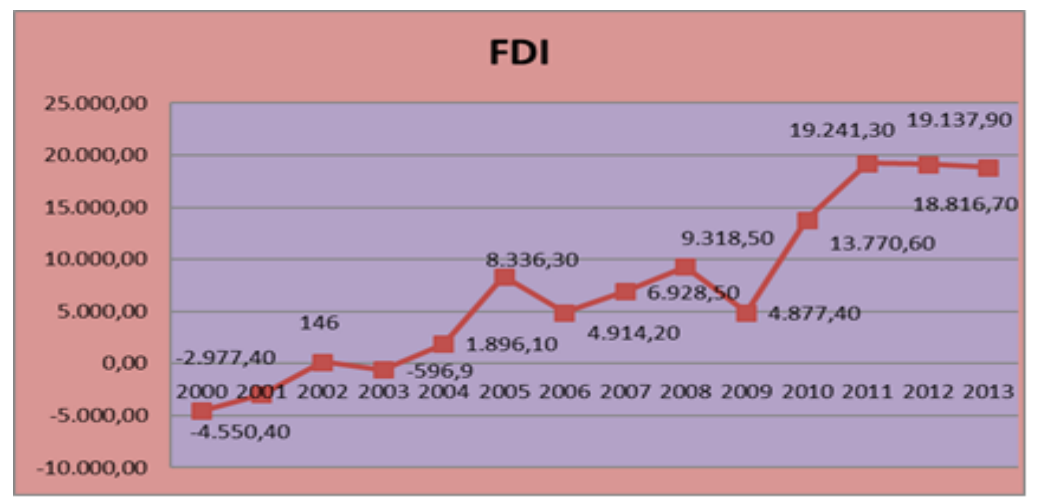

Figure 2: Development of Foreign Direct Investment in Indonesia, 2000 - 2013 
The development of foreign direct investment in Indonesia during the period 2000 2013 experienced very volatile developments. In 2000, foreign direct investment has not shown any positive progress due to low foreign investor confidence in the certainty of investing in Indonesia, particularly in relation to security guarantees, legal certainty, slow restructuring of the business sector, and very high fluctuations in exchange rates (exchange rate risk). . The success in achieving various improvements in macro and monetary indicators is still confronted by structural problems, causing foreign direct investment from 2001 to 2002 to increase to US \$ 145.9 billion.

The continued improvement in Indonesia's economic performance and prospects led to an increase in the role of foreign direct investment (FDI) in foreign capital inflows to Indonesia during 2010. The increase in FDI and private foreign borrowing had a direct impact on real sector performance, with increases mainly in the non-tradable sector. and the industrial sector. Efforts to attract foreign direct investment need to be supported by directing it to the tradable and export-oriented sectors. Meanwhile, alternative sources of financing other than bank credit and foreign direct investment also need to be developed through financial market deepening so that they can take advantage of foreign capital inflows. (Bank Indonesia: 2010).

\section{Development of Gross Domestic Product (GDP)}

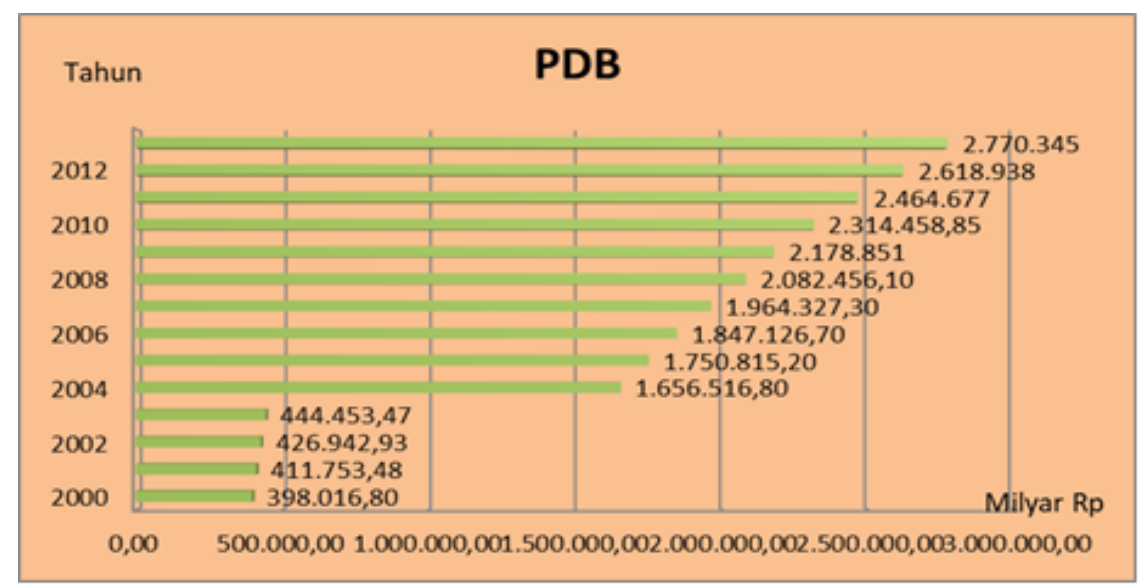

Figure 3: Development of Indonesia's GDP in 2000-2013

Based on the picture above, it explains that the development of Indonesia's GDP from 2000 to 2013 experienced a positive increase and growth. The GDP figures from 2000 to 2003 used constant 1993 prices. So there was a fairly high level of difference in figures from 2003 to 2004. Meanwhile, the GDP from 2004 to 2013 was used based on constant 2000 prices. in 2010 it achieved another increase of $6.1 \%$ from $4.6 \%$ in 2009 . This increase was supported by high growth in export and investment performance, accompanied by strong household consumption. In 2012 to 2013, GDP growth increased to $\mathrm{Rp} 2,770,345$ billion. This increase is through policies carried out by the government that are focused on stabilization efforts by encouraging the economy to grow at a healthier and more balanced rate. 


\section{Real Interest Rate Development}

The real interest rate is the nominal interest rate reduced by the inflation rate. In addition, the real interest rate is also a guideline for investors to see whether their investment is profitable or not. The development of interest rates in Indonesia is shown in the following figure:

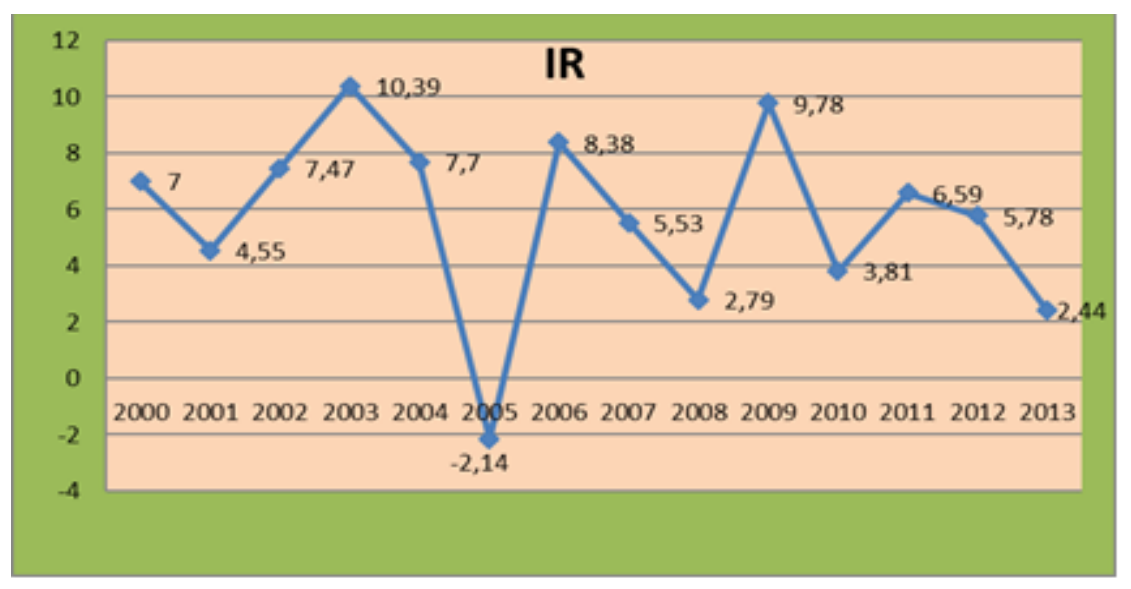

Figure 4: Development of Real Interest Rates in Indonesia 2000-2013

The picture above shows the graph of the real interest rate from 2000 to 2013 experiencing a fluctuating decline. Based on information from the Indonesian economic report published by Bank Indonesia, the low increase in deposit interest rates, amidst the increase in the inflation rate, resulted in a decrease in real interest rates at the end of December 2000. This condition caused the public not to be interested in saving back their currency in banks. . The worsening of economic and monetary conditions was demonstrated by slowing economic growth, weakening exchange rates and high inflationary pressure. So that in 2001 the real interest rate was 4.55\%. In 2004 and 2005, the real interest rate decreased again to $7.7 \%$ and $-2.14 \%$.

\section{Exchange Rate Developments}

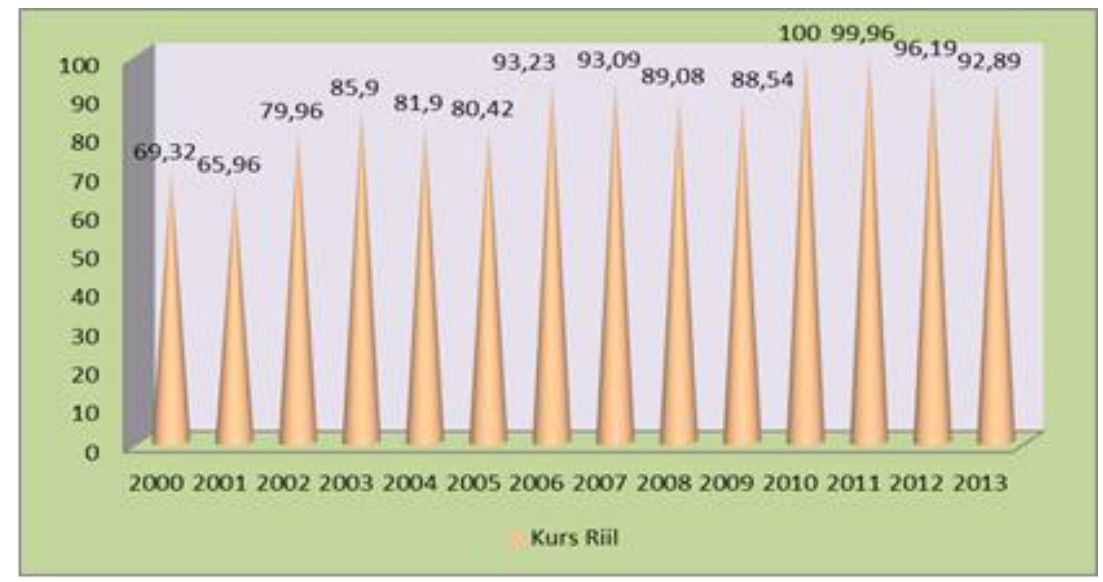

Figure 5: Real Exchange Rate (Exchange Rate) Development in Indonesia 2000 - 2013 
This figure explains that the development of conditions in the real exchange rate in Indonesia during the period 2000 to 2013. The real exchange rate in 2000 was 74.91 percent, then decreased to 71.27 percent in 2001.

\section{Development of Labor Productivity}

Productivity of workers is one measure of a company to achieve its goals. Increasing worker productivity is very important with the demands of the labor market which demands the provision of skilled workers.

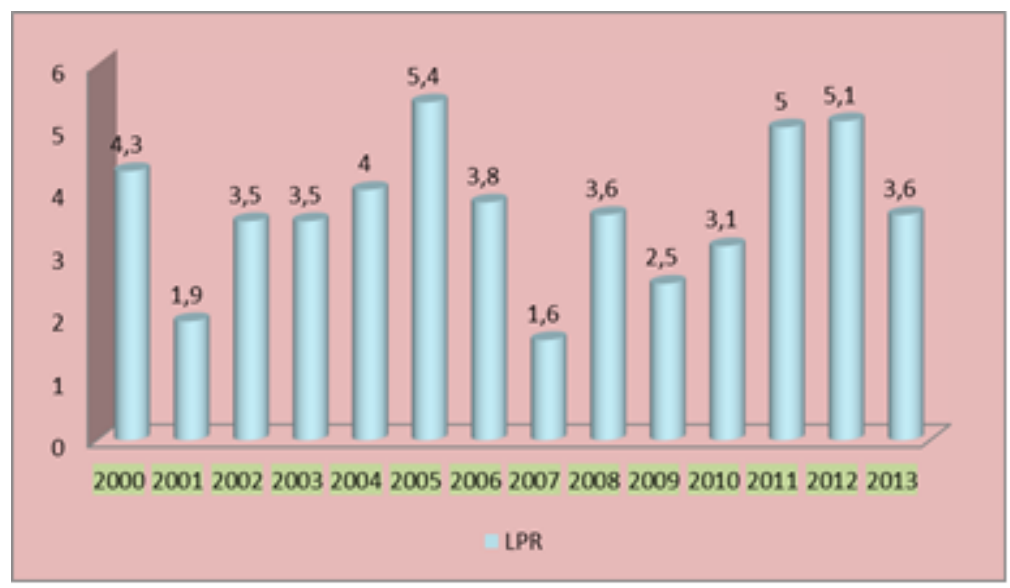

Figure 6: Development of Labor Productivity

Based on the picture above, worker productivity from 2000 to 2013 has experienced a fluctuating decline. Based on information obtained from UNESCAP, in 2000 it was 4.3 percent and decreased in 2001 by 1.9 percent. Then it increased in 2002 by 3.5 percent and in 2003 the development was constant. And in 2004 it has increased to 4 percent.

\section{The Export Development}

Exports are goods and services sourced from within the country to be sold abroad. Exports used are the number of oil and gas exports with non-oil and gas. From Statistics Indonesia data, the development of Indonesia's exports during 2000 to 2013 is presented in Graph 7 below.

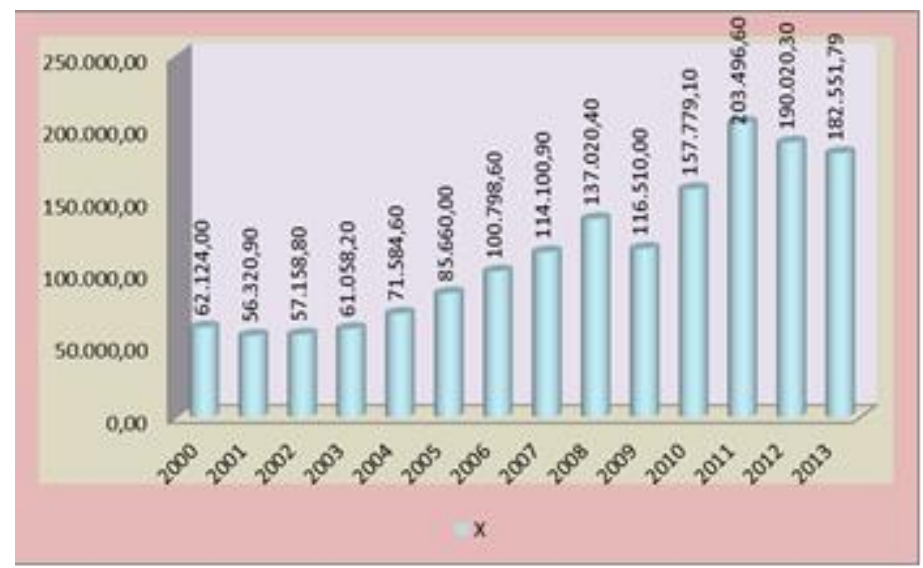

Figure 7: Indonesian Export Development in 2000-2013 


\section{Result of Partial Hypothesis Testing (t-test)}

The partial test results can be seen in the estimates obtained through the t test with a significant level $\alpha=5$ percent. In the short term, the t-statistic and probability value for the gross domestic product variable t-stat $=4.3741$ (prob $=0.0047$ ) indicates that the gross domestic product variable has a positive and significant effect on foreign direct investment in Indonesia.

In the short term, the interest rate variable with $\mathrm{t}$-stat $=-3.0854$ and prob $=0.0215$ indicates that the interest rate variable has a negative and significant effect on foreign direct investment in Indonesia.

The rupiah exchange rate variable with a t-stat value $=6.0255$ and prob $=0.0009$ shows that in the short term, the rupiah exchange rate variable has a positive and significant effect on foreign direct investment in Indonesia.

The worker productivity variable with $\mathrm{t}$-stat $=4.3919$ and prob $=0.0046$ shows that in the short term, the worker productivity variable has a positive and significant effect on foreign direct investment in Indonesia.

And the export variable with a t-stat value $=-4.9601$ and prob $=0.0026$ shows that in the short term, the export variable has a negative and significant effect on foreign direct investment in Indonesia.

\section{Test Results Together (F-test)}

In the short term, the estimation results can be seen that the statistical $F$ value of 33.88837 with a statistical probability of 0.000225 is smaller than $\alpha=0.05$ which indicates that together (simultaneously test) all the independent variables, namely gross domestic product, ethnic level interest, the rupiah exchange rate, labor productivity, and exports as well as the error correction term (ECT) have a significant effect on foreign direct investment in Indonesia.

\section{Estimated Accuracy Test Results}

Based on the estimation results, the coefficient of determination (R-Square) in the shortterm model is 0.971337 , which means that $97.13 \%$ of the variation in changes in foreign direct investment in Indonesia can be explained by the gross domestic product, interest rate, and rupiah exchange rate variables. , worker productivity and exports. While the remaining $2.87 \%$ is explained by variables outside the model (which are not researched).

\section{Discussion of Research Analysis}

This discussion is an interpretation of the regression coefficients estimated from the research model. Statistically, the ECM value was significant. This shows that the equation model can lead to equilibrium when an imbalance occurs. Where the error term is negative, it will cause the coefficient of foreign direct investment in Indonesia (FDI) to be above the equilibrium value so that foreign direct investment in Indonesia (FDI) will decrease to return to the equilibrium condition in the next period or make corrections to the imbalance condition in the next period caused by variables of gross 
domestic product, real interest rate, foreign exchange rate, labor productivity and exports.

\section{Variable Gross Domestic Product (GDP)}

From the estimation results, it can be seen that in the short term the relationship between gross domestic product and foreign direct investment in Indonesia (FDI) is positive and significant with a coefficient of 6.468994 which means that if there is an increase in GDP by 1 percent, it will increase Foreign Direct Investment by 6.468994 percent. . This empirical result is in accordance with the hypothesis proposed based on Keynes's theory, that what affects the amount of saving is the level of income, as well as the interest rate. In an equilibrium condition, the amount of saving must be equal to investment, and this shows that the level of investment actually depends also on the level of income, in the sense that the greater the income, the greater the level of investment, or vice versa. The results of this study are consistent with previous research by Sarwedi (2002: 32), Surianti (2011), Febrina (2014), and Letarisky (2014: 1) that the GDP variable or gross domestic product has a positive and significant effect on foreign direct investment. However, the results of other researchers Sambodo (2003) state that the GDP variable has a positive and significant effect when a crisis occurs.

\section{Variable Real Interest Rate (RIR)}

From the estimation results, it can be seen that in the short term the relationship between the interest rate and foreign direct investment in Indonesia (FDI) is negative and significant with a coefficient of 0.305328 . The meaning of this value can explain that with a confidence level of 97 percent, every 1 percent increase in the interest rate will cause a decrease in foreign direct investment in Indonesia by 0.305328 percent.

This empirical result is in accordance with the hypothesis put forward based on the theory according to Mankiw (2003) that the real interest rate measures the actual cost of borrowing and, thus, determines the amount of investment. because when the interest rate rises, the amount of investment demanded falls, so that there are fewer profitable investment projects. This empirical result is consistent with previous research by Sitinjak (2011), which states that the real interest rate variable has a negative and significant effect on foreign direct investment. Likewise, the empirical results of Sambodo (2003) state that the factor affecting foreign direct investment into Indonesia both before and during the crisis is the interest rate.

\section{Variable Rupiah Exchange Rate (RER)}

Estimates show that in the short term the relationship between the exchange rate and foreign direct investment in Indonesia (FDI) is positive and significant with a coefficient of 0.4922860 , which means that with a confidence level of 97 percent, every 1 percent increase in the rupiah exchange rate against the dollar will cause an increase. foreign direct investment in Indonesia amounted to 0.4922860 percent.

This empirical result is in accordance with the hypothesis proposed based on the theory according to Benassy-Quere (2001), the exchange rate can affect foreign direct investment, depending on the purpose of the goods produced. If investors aim to serve 
the local market, then movements from foreign direct investment are a substitute. So that when the exchange rate increases, this can increase foreign direct investment because the purchasing power of local consumers is higher. This is in line with the theory of remuneration parity according to Bakar (2002) in Sambodo (2003: 25) that if in the long run it is assumed that foreign interest rates are the same as domestic interest rates, then the difference in investment remuneration will only be affected by changes in foreign exchange rates. now and in the future. Meanwhile, if the rupiah exchange rate strengthens, the disparity in remuneration between foreign and domestic investors will decrease. This will make foreign investors prefer to invest in their country, on the other hand, if the exchange rate weakens so that the disparity in remuneration will increase, investors will invest their money abroad. Thus there is a positive relationship between changes in exchange rates and investment.

This empirical result is in accordance with previous research by Yol (2009) and Mohammadvandnahidi (2012) that the real exchange rate has a positive and significant effect on foreign direct investment.

\section{Variable Workforce Productivity (WP)}

The estimation results show that in the short term the relationship between worker productivity and foreign direct investment in Indonesia (FDI) is positive with a coefficient of 1.426944. The meaning of this value can explain that with a confidence level of 97 percent, every 1 percent increase in worker productivity will lead to an increase in foreign direct investment in Indonesia by 1.426944 percent.

This empirical result is in accordance with the results of previous research conducted by Susanto (2012) that the worker productivity variable has a positive and significant effect on foreign direct investment. An increase in worker productivity denotes an increase in the amount of output a worker can produce. Increasing worker productivity will reduce labor costs per unit of output. Determination of labor costs can reduce production costs. Industries with low production costs will be able to compete and at the same time increase their market share. This empirical result is in line with Albulescu's (2010: 94) research that foreign companies also take this factor into account in their investment decisions.

\section{Export Variable (X)}

From the estimation results, it can be seen that in the short term the relationship between exports and foreign direct investment in Indonesia is negative with a coefficient of 20.10881. The meaning of this value can explain that with a confidence level of 97 percent, every 1 percent increase in exports will cause a decrease in foreign direct investment in Indonesia by 20.10881 percent.

In the short term, an increase in the value of FDI causes a decrease in the value of exports. This is because in the short term, the impact of foreign capital inflows into the real sector generally occurs through changes in the real exchange rates of the domestic currency (exchange rates after taking into account the price levels in the related countries). The high inflow of FDI to Indonesia tends to increase demand for the rupiah 
and in the end it has an impact on the appreciation of the value of the rupiah against foreign currencies. The real exchange rate of the domestic currency, which tends to appreciate, could have a negative impact on export performance (weaken export competitiveness in terms of prices). (Bank Indonesia, 2010).

Likewise, according to Antoni (2008: 29), the relationship between exports and FDI is complementary to one another. In other words, increasing exports in a country will encourage foreign investment into that country. Conversely, if the export yield is negative and significant, then the relationship between exports and FDI is mutually substituting between one another. In other words, an increase in exports will cause foreign direct investment to decline. These empirical results are consistent with previous research by Yol (2009) that exports have a negative and significant effect on foreign direct investment.

\section{CONCLUSIONS AND RECOMMENDATIONS}

\section{Conclusion}

1. The estimation results of the coefficient of determination in the short term, the variable foreign direct investment in Indonesia can be explained by the variables of gross domestic product, interest rates, rupiah exchange rate, worker productivity and exports.

2. From the estimation results obtained, the variables of gross domestic product, rupiah exchange rate, and worker productivity have a positive and significant effect on foreign direct investment in Indonesia in the short term. Meanwhile, the real interest rate and export variables have a negative and significant effect on foreign direct investment in Indonesia.

3. The magnitude of the coefficient value of the variables that explain the Foreign Direct Investment variable, the largest is the Gross Domestic Product variable, followed by worker productivity, the rupiah exchange rate, and the real interest rate, respectively.

\section{Suggestion}

1. The government needs to increase the improvement of foreign investment policies and regulations that support government policies to increase interest in foreign investment through labor law certainty, improving tax regulations and facilitating licensing. In addition, the government is expected to increase sociopolitical stability and security so that investors are not worried about investing their capital.

2. In controlling the rate of foreign direct investment, the government needs to strengthen the economic structure so that it is not susceptible to shocks by maintaining the stability of macroeconomic variables as an effort to increase foreign direct investment in Indonesia. In particular, the variables of Gross Domestic Product, real interest rates, the rupiah exchange rate and worker productivity can significantly influence foreign direct investment. 
3. The government should further encourage and provide socialization about the importance of maintaining the quality of products produced by domestic entrepreneurs so that products produced domestically can compete in the global market and this will develop exports through industrial strategies.

4. In further research, the research object should be expanded by adding variables related to foreign direct investment and which have not been included in this research.

\section{REFERENCES}

Ajija, dkk. 2011. Cara Cerdas Menguasai Eviews. Jakarta : Penerbit Salemba Empat

Albulescu, Claudiu Tiberiu., Briciu, L \& Coroiu, S.I. 2010. Determinants of Foreign Direct Investment in CEECS : The Role of Financial Stability. JEL Clasification : G11, G24, O16, P33

Anastasia, Henny Maria. 2010. Faktor-Faktor Ekonomi Makro yang Mempengaruhi Investasi Asing Langsung (FDI) pada Sektor Perkebunan di Indonesia Periode (Tahun 1980 - 2007). Tesis. Magister dan Perencanaan Kebijakan Publik Kekhususan Infrastruktur. Universitas Indonesia

Antoni. 2008. Investasi Langsung Asing (FDI) dan Perdagangan: Bukti Empiris di Indonesia. Jurnal Ekonomi Bisnis dan Koperasi. Vol. 10 No. 2

Apridar. 2009. Ekonomi Internasional. Graha Ilmu. Yogyakarta

Bank Indonesia, 1993-2013. Statistik Ekonomi dan Keuangan Indonesia

Bank Indonesia. Laporan Perekonomian Indonesia Berbagai Edisi. Jakarta :

Badan Pusat Statistik. Statistika Indonesia. Jakarta

Benassy-Quere, A.,Fontagne,L. dan Lahreche-Revil, A. 2001. Exchange-Rate Strategies in the Competition for Attracting Foreign Direct Investment. Journal of the Japanese and International Economies, 15,178-198

Bunga, Redemta dan Sukarsa, Made I. 2015. Pengaruh PDB, Suku Bunga dan Nilai Total Ekspor investasi asing langsung di Indonesia (1993-2012). E-Jurnal Ekonomi Pembangunan Universitas Udayana. Vol.4 No.8, Agustus 2015

Case, Karl E dan Fair, Ray C. 2007. Prinsip-prinsip Ekonomi. Edisi Kedelapan. Alih bahasa Wibi hardani dan Devri Barnadi. Jakarta : Erlangga

Dewata, Bobby Kresna dan Swara, I. Wayan Yogi . 2003. Pengaruh Total Ekspor, LIBOR, dan Upah Tenaga Kerja Terhadap Investasi Asing Langsung di Indonesia. E-Jurnal Ekonomi Pembangunan Universitas Udayana Vol.2 No.8 :350-358

Dornbusch.R, Fischer dan S. Startz, R. 2004. Makroekonomi. Edisi Bahasa Indonesia. PT Media Global Edukasi

Febrina, Puspa dan Sumiyarti. 2014. Pengaruh Kebijakan Makroekonomi dan Kualitas Kelembagaan terhadap Foreign Direct Investment di ASEAN-6-Analisis Panel Data. Jurnal Ekonomi Pembangunan Trisakti (e-Journal). Vol.1 No.2, September 2014

QE Journal |Vol.09 - No.01 - 34 
Gujarati, N, Damodar. 2012. Dasar-dasar Ekonometrika (Terjemahan). Buku2. Edisi 5. Penerbit Salemba: Jakarta

Hady, Hamdy. 2001. Ekonomi Internasional. Buku 2. Edisi Revisi. Jakarta. Penerbit Ghalia Indonesia

Insukrindo. 1999. Pemilihan Model Ekonomi Empirik dengan Pendekatan Koreksi Kesalahan. Jurnal Ekonomi dan Bisnis. Vol. 14 No. 1. 1-8

Jhingan, M.L. 1994. Ekonomi Pembangunan dan Perencanaan. Jakarta. PT Raja Grafindo Persada

Khan, Rana Ejaz Ali et al. 2010. Economic Determinants of Foreign Direct Investment in Pakistan. J Economis, 1(2) : 99-104

Kurniati,Yati., Prasmuko, Andry dan Yanfitri. 2007. Determinan FDI : Faktor-faktor yang Mempengaruhi Investasi Langsung. Working Paper. Agustus 2007

Letarisky, Monica., Darminto dan Hidayat, Rustam R. 2014. Pengaruh Indiktor Fundamental Makroekonomi terhadap Foreign Direct Investment di Indonesia (Periode Tahun 2004-2013). Jurnal Administrasi Bisnis (JAB) / Vol. 15 No. 2 Oktober 2014

Mankiw, N. Gregory. 2007. Teori Makroekonomi. Edisi Keenam. Jakarta: Erlangga

McEachern, W. A. 2000. Ekonomi Makro Pendekatan Kontemporer. Edisi Pertama. Jakarta: Salemba Empat

Mohammadvandnahidi, Reza Mohammad., Jaberikhosroshahi, N \& Norouzi, D. 2012. The Determinants of Foreign Direct Investment in Iran : Bounds Testing Approach. Economic Research Ekonomska Istrazivanja. Vol. 25(3)

Nanga, Muana. 2005. Makroekonomi: Teori, Masalah dan Kebijakan. Jakarta : PT Raja Grafindo Persada

Nopirin. 2000. Ekonomi Moneter. Buku II. Yogyakarta: BPFE

Pambudi, Adhib Eka dan Hakim, Lukman. 2013. Perbandingan Faktor Ekonomi Makro dan Karakteristik Negara Sebagai Determinan FDI di ASEAN 5 dan China periode 1988-2009. Dinamika Jurnal Ekonomi Pembangunan. Vol.5 No.1, Februari 2013

Putong, Iskandar dan Andjaswati, N.D. 2008. Pengantar Ekonomi Makro. Edisi Ke Satu. Jakarta. Penerbit Mitra Wacana Media

Ralhan, Mukesh. 2006. Determinants of Capital Flows: A Cross-Country Analysis. Econometrics Working Paper EWP0601. Canada: Departements of Economics. University of Victoria Canada.

Salvatore, Dominick. 1997. Ekonomi Internasional. Edisi Ke lima. Jilid satu. PT Gelora Aksara Pratama. 
Sambodo, A.M. 2003. Analisis Faktor-faktor yang Mempengaruhi Penanaman Modal Asingdi Indonesia. Tesis. Magister Ilmu Ekonomi Studi Pembangunan. Universitas Diponegoro

Samuelson, Paul dan Nordhaus, William. D. 2004. Ilmu Makroekonomi. PT Media Global Edukasi. Jakarta

Sarwedi. 2002. Investasi Asing Langsung di Indonesia dan Faktor yang Mempengaruhinya. Jurnal Akuntansi dan Keuangan. Vol.4 No.1

Saswa, Sugiri Trisnaning. 2012. Analisis Faktor-faktor yang Mempengaruhi Investasi Asing Langsung di Indonesia. Tesis. Medan : Universitas Negeri Medan

Sitinjak, Robudi Musa. 2011. Analisis Faktor-faktor yang Mempengaruhi Penanaman Modal Asing Langsung di Indonesia. Tesis. MPKP FE UI, Universitas Indonesia

Surianti, Eni. 2011. Analisis Faktor-faktor yang Mempengaruhi Penanaman Modal Asing Langsung di Indonesia. Tesis. Medan : Universitas Negeri Medan

Sukirno, S. 2008. Makro Ekonomi Teori Pengantar. Jakarta. PT. Raja Grafindo Persada

Supriana, Tavi. 2008. Ekonomi Makro. Medan. USU PRESS

Susanto, Joko. 2012. Determinan Penanaman Modal Asing Langsung di ASEAN. JRMB. Vol.7 No.1, Juni 2012

UNESCAP, http://www.unescap.org/stat/

Waluyo, Dwi Eko. 2007. Ekonomika Makro. Edisi Revisi. Cetakan Kelima. Malang. UMM PRESS

Winarno, Wahyu Wing. 2011. Analisis Ekonometrika dan Statistika dengan Eviews. Edisi 3. Yogyakarta: UPP STIM YKPN

Yol, Maria and Ngie, Teng Teng. 2009. Estimating The Domestic Determinants of Foreign Direct Investment Flows in Malaysia : Evidence From Cointegration and ErrorCorrection Model. Jurnal Pengurusan 28, 3-22 